\title{
Calling for a Reset in Turkish-American Relations in the post-COVID International Order
}

\author{
MUSTAFA KIBAAROĞLU \\ MEF University, Turkey \\ ORCID No: 0000-0003-1147-9363
}

\begin{abstract}
Analysts emphasize that nothing will be the same after the pandemic and refer to the 'new normal' that is likely to prevail everywhere in the world. It would be a legitimate question to ask if this would provide a conducive environment for Turkey and the United States to reset their relations that have much deteriorated lately. This article will, first, highlight the contours of the 'new normal' narrative by referring to the views expressed by politicians, academics, analysts, journalists and intellectuals from around the world. Second, the article will assess the implications of the parameters of the 'new normal' for key actors in world politics, such as the United States, China, the European Union and Russia, as well as Turkey's Middle Eastern neighbors, with respect to the issues that will be at stake in the international security environment. Finally, the article will make a call for a reset in Turkish-American relations in order for the two long-standing allies to adapt themselves better to post-COVID international politics.
\end{abstract}

Keywords: Turkey-U.S. Relations, International Order, NATO, China, COVID-19

Insight Turkey 2020

Vol. 22 / No. 2 / pp. 93-109 


\section{Introduction}

he coronavirus pandemic that has claimed the lives of hundreds of thousands of people in a span of a few months has shown unequivocally that a microscopic agent may knockout gigantic military powers, shut down prosperous economies and halt the mobility of billions of people in every corner of the world. Such developments have unearthed, among other things, what was indeed lying just beneath the fancy surface of many states and international organizations in terms of their capacities and capabilities to govern their constituents.

Most analysts who have shared their estimates about how the world might look like in the near future emphasize that nothing will be the same after the pandemic. They also frequently use the term 'new normal' in their jargon to describe the 'new code of conduct' that is likely to prevail everywhere in the world and in almost every aspect of life for at least quite some time to come. Should this be the case, be it in business or in politics, it would be a legitimate question to ask if the 'new normal' could provide a conducive environment for Turkey and the United States to review and then to reset their relations, which have deteriorated significantly over the past several years.

With that in mind, this article will, first of all, highlight the contours of the 'new normal' narrative that is gaining ground in the media and in the discourse of international politics, by referring to the views expressed by politicians, academics, analysts, journalists and intellectuals from around the world.

Second, the article will assess the implications of the parameters of the 'new normal' for key actors in world politics such as the United States, China, the European Union (EU) and Russia, as well as for Turkey's neighbors, namely Iran, Iraq and Syria, with respect to the issues that are and will be at stake in the international security environment. Finally, the article will make a call for a reset in Turkish-American relations in order for the two long-standing allies to be able to adapt themselves better to the new codes of conduct in the 'new normal' order in international politics.

\section{Contours of the 'New Normal' Narrative in Post-COVID International Politics}

When breaking news about the epidemic originating from China's Wuhan city made the headlines on TV channels, the typical reaction of most of the states in the world was to close their air, land and sea borders to outsiders, albeit gradually, due to their delayed acknowledgment of the seriousness of the situation, so as to be able to control the extent and the pace of the contagion. 
Starting in late February 2020, the world maps that were displayed on the TV screens every night looked like a big puzzle whose parts were being found and put in their proper places, one by one, and which was moving toward completion rather fast. Within less than a month, by mid-March, the puzzle was almost complete. More than 185 countries in the world were infected with COVID-19, and a mounting number of cases were being declared to the World Health Organization (WHO) every day.

After being hit by the blitzkrieg of the notorious virus, governments around the world quickly turned inward, put aside their non-essential routines, no matter what, and tried to wrangle with the virus. more swiftly while the virus was obviously toppling other countries like dominos, one after another, taking its toll on its way toward them.

Italy and Iran were recorded as the first countries after China to fall victim to the pandemic and suffer an unprecedentedly fast-rising death toll. Spain and Germany, not to mention the United Kingdom, soon joined them. Authorities at the WHO, therefore, declared that the "epicenter of the pandemic," an unpleasant title that would soon be shared with North America, had shifted from Asia to Europe. ${ }^{1}$

The first couple of weeks of the pandemic were the most difficult timeframe for state governments in their fight against the virus, as they were caught unprepared in all respects, from the lack of proper therapeutics to the scarcity of protective gear for healthcare professionals, and from the insufficient number of intensive care units (ICU) to testing kits. Ironically though, concerned authorities in the scientific communities and the relevant branches of the state apparatus of the respective governments that had been specifically tasked with assessing and anticipating such devastating developments in the future, had long ago published reports and issued repeated warnings to that effect.

Under these circumstances, which are continuing unabated with only slight improvements in several countries depending on their reported 'success' in 'controlling' the pace of the spread of the virus, the narrative that 'nothing will ever be the same again in the post-COVID-19 era' has started to gain much currency. 


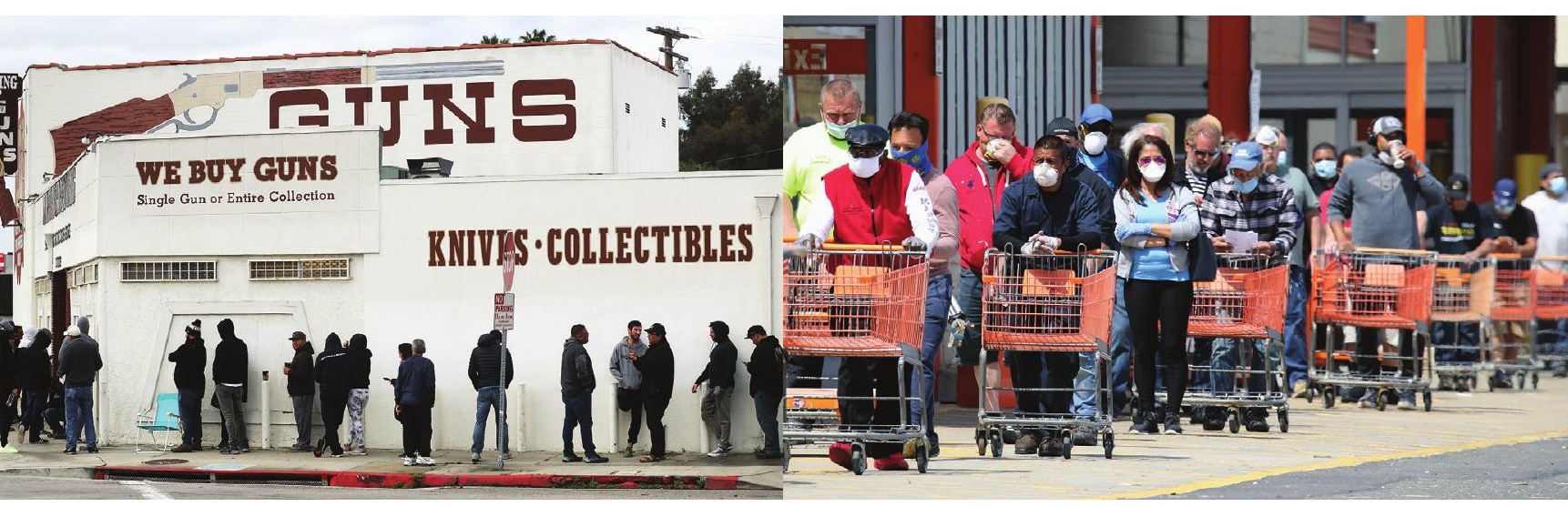

American

citizens line up at gun stores and markets as a climate of anxiety dominates due to the coronavirus pandemic, March 15 and May 20,

2020.

MARIO TAMA / Getty Images

BRUCE BENNETT / Getty Images
Politicians, academics, analysts, journalists and intellectuals from around the world express their views by approaching the issue from different perspectives with a view to making a proper assessment of how the 'new normal' international order might look, and what the parameters of the 'new code of conduct' in every aspect of life might be, extending from business to international politics and security, to education and basic government services. Below is a brief compilation of various perspectives on this matter.

Itty Abraham, Professor, and Head of the Department of Southeast Asian Studies at the National University of Singapore, poses a fundamental question as to what the coronavirus pandemic means for our collective futures. Reminding us that there have been remarkably few truly global turning points in the last century and a half, such as the World Wars and the Great Depression that meet that high standard, he argues that calling the COVID-19 coronavirus pandemic a historic turning point is no small matter. Abraham elaborates on the four future scenarios offered by pro-state progressive optimists, end-of-globalization pessimists, disaster capitalism pessimists and techno-optimists. He then offers two conclusions: First, in the absence of concerted social action within and across national boundaries, the likelihood of change in the direction of inclusion and fairness, however desirable and possible, is very low. Due to the power of vested interests and the social tendency to fear any alteration of the status quo, even a world-historic turning point (from the standpoint of exposing human vulnerabilities) may not change very much. Second, what is unique about the COVID-19 pandemic is its lack of discrimination and universality of reach, joined with the absence of a distinct end-point to the crisis. What is not different is the unevenness of who is affected and who suffers more. This crisis, according to Abraham, is not a historic moment or 'turning point' as much as it is a historical process. The difficulty of coming to terms with this ongoing crisis in its fullness comes from the complexity of the intersections of these three characteristics: universality, endlessness, and unevenness. ${ }^{2}$ 
Zachary Abuza, Professor at the National War College in Washington, D.C., maintains that the pandemic will cause a sharp economic downturn in Southeast Asia that will result in shrinking defense budgets and declining arms imports. This situation, according to Abuza, could force a rethinking of defense priorities while the COVID-19 pandemic will also have repercussions for civil-military relations. Hence, Abuza argues, Southeast Asian states will be coping with unemployment, food insecurity and a decline in foreign investment and exports. Accordingly, the global economic downturn, coupled with a surge in anti-immigrant sentiment, will have a major impact on the region's migrant workers, whose remittances are so critical to their home states' economies, driving down domestic consumption and having crucial effects on such sectors as banking, real estate and service industries. ${ }^{3}$

Ashley J. Tellis, a Senior Fellow at the Carnegie Endowment for International Peace, asserts that the U.S. economy will face important transitions after this pandemic in at least two directions for the future of its national power. First, Tellis believes, it is likely that the unrestrained globalization that evolved over the last several decades -driven largely by the profit-maximizing behaviors of private entities- will be replaced by a more constrictive version of interdependence in which states seek to protect critical aspects of the production chain within national boundaries as an insurance against future vulnerability. Second, Tellis argues, short of an armed attack on the United States, the competition for public resources between nondefense and defense goods is likely to intensify. Tellis also adds that, at the moment, the United States appears to believe that bilateralism is a sufficient substitute for friendly coalitions and that its alliances are little more than the burdensome legacies of history with minimal relevance to the strategic competition that lies ahead. ${ }^{4}$

James Crabtree, Associate Professor at the Lee Kwan Yew School of Public Policy, claims that economies in Latin America look especially fragile and that even if they manage to avoid the virus, poorer nations will be hard hit by the global economic fallout. He argues that the likes of Brazil, Russia and South Africa -all lauded until recently as part of the superstar BRICS group- will decline by five percent or more, and that still weaker figures are likely if outbreaks spread, which in turn are likely to undermine more hopeful projections for $2021 .^{5}$ 


\section{İbrahim Kalın, the Turkish Presidential Spokesman, maintains that the COVID-19 outbreak has laid bare the global order's immune system, which has turned out to be much weaker than was thought. Three elements of the ecosystem will gain crucial importance in the post-virus world: bio-security, cyber- security, and food security}

Nikolas K. Gvosdev, an Editor at the National Interest magazine, believes that the coronavirus is testing existing alliance relationships and causing fractures in the current setup of globalization. It is also challenging the wisdom of over-relying on a single great global-market continuum to provide the goods and services necessary both for prosperity and security. On the other hand, despite these impacts, Gvosdev contends, it does not create one single shock, as in $9 / 11$, which leads to a pause. ${ }^{6}$

Burak Akçapar, Head of Policy Planning Department at the Turkish Ministry of Foreign Affairs, believes globalization will be seriously challenged by regionalization, big and small, due to the sensitivity and the fragility of the existing supply lines that has been experienced during the current pandemic. Moreover, Akçapar argues, digitalization of the economies worldwide, thanks to the ever-expanding use of Artificial Intelligence, 5G telecommunication technologies, 3D printing, and the like, local production will gain pace, eventually carrying China to the top of the list of the largest economies in the world in the foreseeable future. ${ }^{7}$

Edward Fishman, Former Member of the Policy Planning Staff at the U.S. State Department, formulates a role for the United States in the post-COVID world order and suggests that America should fund the institutions of the new order so they are capable of averting the next crisis before it spirals out of control. According to Fishman, the post-coronavirus order should be grounded in domestic consensus, and thus the U.S. and its allies in Europe and Asia should come together into a council of democracies, expanding collective defense beyond the military realm to counter election meddling, disinformation and financial coercion. On the economic front, he argues, America, the EU, Japan and other democracies should seal new economic agreements in which increasing market access goes hand-in-hand with cracking down on tax avoidance, protecting data privacy and enforcing labor standards. ${ }^{8}$

Josep Borrell, the High Representative of the European Union for Foreign Affairs and Security Policy, suggests that in the post-coronavirus world, Europe should not restrict its strategic autonomy to the military sphere alone. In that sense, Borrel defines six pillars around which Europe's strategic autonomy 
must be built: (i) reducing dependency, not only in the healthcare sector but also in the field of future technologies like batteries and artificial intelligence; (ii) preventing market players from outside Europe from taking control of its strategic activities; (iii) protecting Europe's critical infrastructure against cyberattacks; (iv) ensuring that Europe's decision-making autonomy will never be undermined by the offshoring of certain economic activities and the dependence that creates; (v) extending Europe's regulatory powers to cover future technologies to prevent others from regulating in a way that is detrimental to Europe; and (vi) showing leadership in all areas where a lack of global governance is destroying the multilateral system. ${ }^{9}$

Mehdi Sanaei, Senior Lecturer at Tehran University's Department of International Relations, claims that without a doubt, in the post-coronavirus period, national sovereignty and the role of the state institution will be strengthened, and the basic economy and investment in healthcare will be highlighted. In the meantime, despite the failure of globalization processes, countries will seek to find a global mechanism to deal with crises and common threats in the international arena. Multilateralism will also be strengthened in global politics, and countries will move further away from American globalization. According to Sanaei, the main loser in this crisis is the economy in different areas such as energy, the aviation industry and tourism, and the winner is virtual technology and various areas of the cyber industry. Due to the serious damage that this crisis is inflicting on the credit and economy of the United States and Europe, and the EU's failure in helping its member states, the image of the East will become more highlighted and prominent in the eyes of the world. Under these circumstances, Sanaei argues, countries such as China, Russia, India, as well as Iran will be able to be more active, and Iran, with the relative easing of this crisis, can enjoy its capacities and potentials to form an international partnership and coalition to deter unilateralism and expand cooperation in Eurasia and West Asia. ${ }^{10}$

İbrahim Kalın, the Turkish Presidential Spokesman, maintains that the COVID-19 outbreak has laid bare the global order's immune system, which has turned out to be much weaker than was thought. According to Kalın, three elements of the ecosystem will gain crucial importance in the post-virus world: bio-security, cyber-security, and food security. Hence, biological products, treatment methods and vaccines, as well as the bio-terror threat will be among the main topics of public health and national security, and these security issues will bring up the need for new regulations between countries and in global markets. Countries with strong agriculture and livestock infrastructure, Kalın argues, will be among the winners in this process. He further states that the era when the big fish can get away with swallowing the small one has gone; it is replaced by an age in which the smart and agile fish can find itself the safest path in turbid waters. Thus countries, regional alliances and international in- 


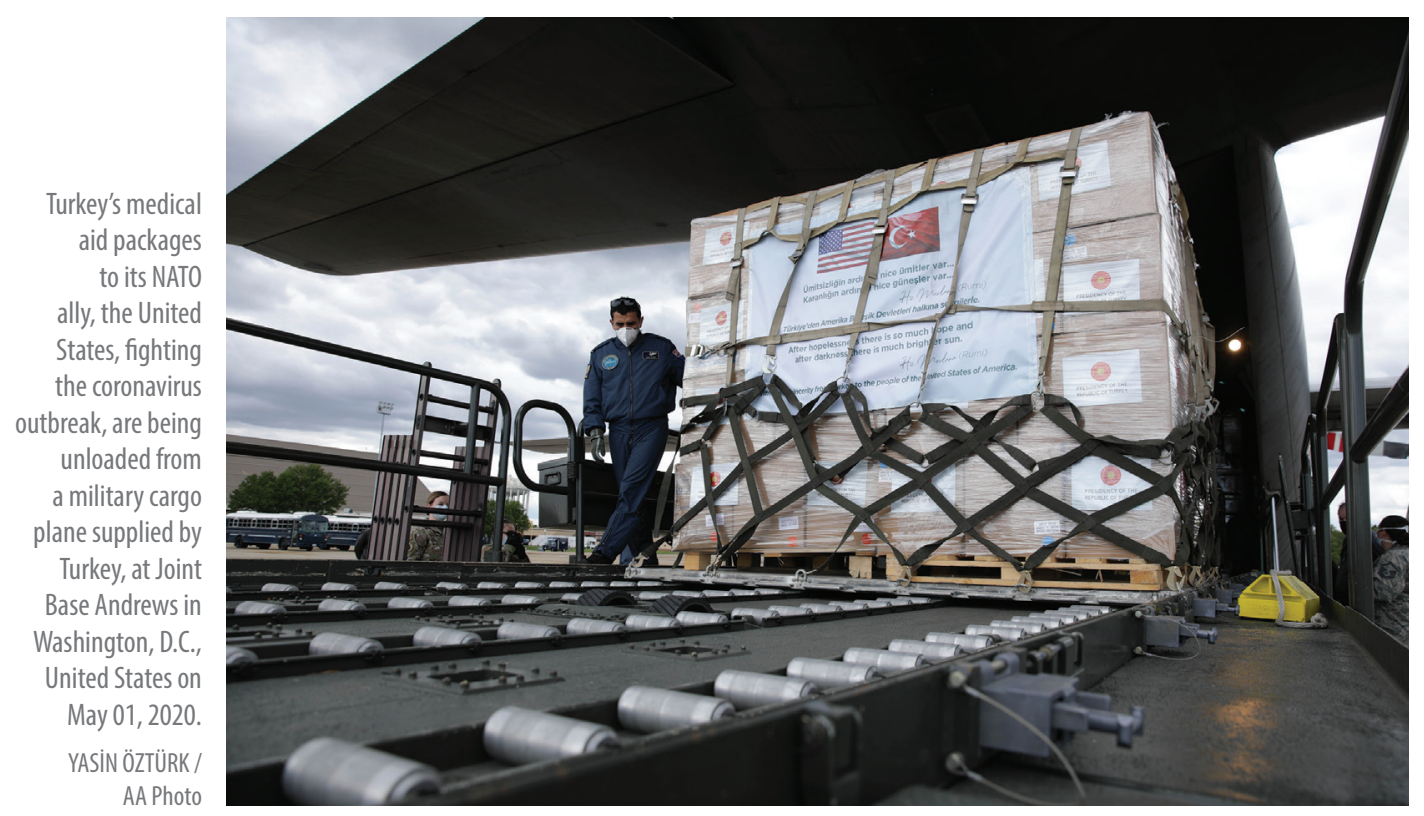

stitutions and organizations, Kalın believes, will have to act in light of this fact in the aftermath of the pandemic. ${ }^{11}$

\section{Implications of the 'New Normal' International Order for International Security}

It's too soon to make highly precise forecasts as to how security relations between global as well as regional powers might be affected by the pandemic, which mercilessly keeps taking its heavy toll worldwide. ${ }^{12}$ Yet, the views highlighted in the above section may provide the reader with the contours of the picture that is highly likely to emerge in the international arena soon, thereby enabling one to assess the implications of the post-COVID environment for international security and stability. There are several recurring themes in the analyses and forecasts widely available in the media outlets, such as the deterioration of relations between the United States and China, the worsening of the economic supremacy of the European Union and the fragility of the regimes in the Middle East.

\section{U.S.-China on a Collision Course}

According to Burak Akçapar, the United States and China are being pulled toward a collision, where the possibility of a kinetic confrontation cannot be totally overlooked, unless they strike a balance in their medium- to long- 
term strategies with respect to the promotion of their 5G technologies; such a collision would, in turn, cause deep divergences among the countries in the rest of the world that are their potential customers. This particular issue alone may become a source of polarization paving the way toward the formation of two different camps, led by the United States and China, respectively, in the age of digital economies. ${ }^{13}$

\section{The pandemic will lead to the end of Europe's integration project, the end of a united, functional America, and the end of the implicit social compact between the Chinese state and its citizens}

Similarly, Kevin Rudd, Former Prime Minister of Australia, reminds us that China has become significantly more assertive in its foreign policy recently, taking calculated risks to bring about changes on the ground, as demonstrated by island reclamation in the South China Sea and the Belt and Road Initiative. Hence, China's posture toward the United States, including on issues such as Taiwan -the single most destabilizing element in the U.S.-Chinese relationship- may be hardened, and the understandings of the 'one China policy' that underpinned the normalization of U.S.-Chinese relations in 1979 could begin to unravel. Rudd, therefore, argues that the world is starting to look like Cold War 1.5, and new threats that both the United States and China are making as COVID-related tensions grow could change the world. As U.S.-Chinese confrontation grows, the multilateral system and the norms and institutions underpinning it will start to stumble and many institutions will become arenas for rivalry. Hence, with a damaged United States and a damaged China, Rudd believes, there will be no "system manager" to keep the international system in functioning order. ${ }^{14}$

"Frank" Ka-Ho Wong, Research Assistant at the Education University of Hong Kong, asserts that the COVID-19 crisis has caused frictions between China and Russia, but is unlikely to undermine their partnership, which is driven by systemic factors, namely their resistance to American hegemony. Both China and Russia oppose the Western-centered world order. According to Wong, the United States' sanctions on Russia and the pursuit of a trade war with China has pushed the two countries even closer together. As the COVID-19 pandemic has underlined pragmatism in Russia-China relations, Wong argues, Putin and $\mathrm{Xi}$ will hope their phone calls will help reduce tensions on the ground. With looming prospects of a new bipolar order after the coronavirus, Russia will likely team up with China against the United States. ${ }^{15}$

\section{EU May End Up Broke, or Even Broken}

James Carafano, the Heritage Foundation's Vice President for Foreign and Defense Policy Studies, asserts that the influence of China will threaten the free- 
For at least two decades, if not longer, in the big questions of international diplomacy and governance, Europe has been a bystander or a helping hand, not a mover and shaker dom, prosperity, and security of the transatlantic community, and he underscores the roles of NATO and the EU in responding to China's challenge on the grounds that Chinese actions and power could well erode NATO's capacity to exercise self-defense. Thus, Carafano claims that the United States and Europe need each other more than ever and that leaders on both sides of the Atlantic should strengthen their partnership to handle China. Accordingly, the United States, being a global power with global interests and responsibilities to participate in protecting the transatlantic community, must face China in the Indo-Pacific and achieve a stable Middle East. Hence, for the U.S. to do all three well, Carafano argues, NATO must do its part -particularly in dealing with the great external threats to European security, and NATO's top priority must be countering the destabilizing activities of Russia. The second major threat, according to Carafano, is that the problems of the Middle East may spill over into and destabilize Europe. Thus, to confront all of those very real possibilities, NATO needs to have the capacity and capability to look and act south toward the Middle East. ${ }^{16}$

Arvind Subramanian, Former Chief Economic Adviser to the Government of India, discusses the impacts of the COVID-19 crisis on Europe, the U.S. and China. He argues that the pandemic will lead to the end of Europe's integration project, the end of a united, functional America, and the end of the implicit social compact between the Chinese state and its citizens. As a result, all three powers will emerge from the pandemic internally weakened, undermining their ability to provide global leadership. ${ }^{17}$

In the view of Jan Techau, Senior Fellow and Director of the Europe Program at the German Marshall Fund of the United States, it is clear that the big geopolitical loser of the pandemic is likely going to be Europe. The main reason, according to Techau, is that Europe could end up being too broke to be resilient, or a shaper of foreign policy outcomes on its own continent, let alone the world. For at least two decades, if not longer, in the big questions of international diplomacy and governance, Europe has been a bystander or a helping hand, not a mover and shaker. It remains unable to guarantee its own security or the larger system of rules on which its economic welfare rests. It was, and is, in other words, a largely derived power, i.e. derived from Washington. Techau further argues that today, the geopolitical experiment called Europe (i.e., the EU) has been hit hard by the coronavirus and will be forced to spend its last savings on getting out of the crisis without leaving millions impoverished and its political wiggle room gravely diminished. Hence, significant money needs to be earmarked to buy Europe back into the geopolitical game in its immedi- 
ate neighborhood. But not just the periphery is at risk, according to Techau; the center has softened too, and this is what makes this meltdown so dangerous. ${ }^{18}$

\section{The Middle East in Deeper Turmoil}

Khairallah Khairallah, a Lebanese writer, asserts that the first remarkable consequence of the pandemic is the plunge it caused in oil prices, as demand for oil fell and economic slumber gripped the world, and that this in itself is going to have tremendous consequences far more serious than the pandemic alone. One should, therefore, expect a post-COVID-19 world and a post-oil-andgas-recession world. According to Khairallah, what is for certain is that many countries will find themselves facing serious danger. Among them will be Iran, Iraq and Syria, of which the latter is not going to find anyone willing to invest in its reconstruction, which is estimated at between $\$ 200$ billion and $\$ 500$ billion. Even in the unlikely event that Syria arrives soon at a settlement, Khairallah argues, the biggest hurdle will be finding donors and businesses willing to invest in the reconstruction of post-war and post-COVID-19 Syria. Khairallah further claims that Iran insists on playing the role of dominant power in the region, but it can offer nothing in the post-oil crisis world. Even Russia itself is in the process of revising its Syrian strategy because it realizes quite well that the post-COVID-19 and post-oil crisis world is going to be quite different from the one of its heyday in Syria. So, it is now forced to rethink its strategy in Syria and compromise with Turkey, which now controls part of northern Syria. The picture is even bleaker for Iraq, which is mired in a deep crisis; Khairallah asserts that since 2003, hundreds of billions of dollars have found their way to the state treasury, but then evaporated into thin air, drained by a corrupt system based on cronyism and sectarian quotas. Hence Iraq, where ninety percent of its revenue comes from oil, is now penniless. The situation in other regional countries is no better than the ones mentioned here. With the drop in oil prices, the region's future seems bleak. Some countries like Lebanon may choose to place themselves with the so-called axis of resistance, which is now bankrupt and has nothing to offer except sectarian militias and empty slogans. Who will come to their aid now is uncertain and, Khairallah argues, it will certainly not be the Arab states from which they estranged themselves. It goes without saying that the Middle East can expect major upheavals and deeper turmoil in a COVID19-tested, oil-lite world. ${ }^{19}$

\section{Prospects for a Reset in Turkish-American Security Relations in the "New Normal" Era}

Against all odds, the anticipated changes in the world as a result of the COVID-19 pandemic may provide a conducive environment for Turkey and the United States to review thoroughly and then reset their relations, particularly in the security domain that has much deteriorated in recent years. 


\section{Turkish-American relations have been considerably strained over the substantial and sustained logistical and other support of the United States to the YPG/PYD even though the group is listed by the State Department as a terrorist organization}

For the greater part of the past seven decades, Turkish-American security relations could be characterized as an 'alliance within the Alliance.' This was mainly due to the attitude of the Western European members of NATO who had long considered Turkey's neighborhood in the Middle East as 'out of area' of their commitment to solidarity with the allies (read Turkey), which was solemnly expressed in Article 5 of the Washington Treaty signed on April 4, 1949. ${ }^{20}$ Turkey and the United States had to figure out alternative ways on a bilateral level to overcome the reluctance of their European allies so as to be able to cope with the security challenges and threats from which they chose to stay aloof.

Nonetheless, there were also crises in the bilateral relations between Turkey and the United States throughout these years, both during the Cold War period and also in its aftermath, emanating mainly from intervening factors owing much to the conflicts of interest between Turkey and third parties such as Greece, Armenia, the Kurds in Iraq (and now in Syria), or Israel lately, in which case, the United States seemed to the Turks to be leaning toward favoring their opponent.

Crises arising purely from the divergences of respective policies that were adopted by Ankara or Washington were rather rare. To cite one particular incident, the opium case, or "the Poppy Problem" may be mentioned here. ${ }^{21}$ In the late sixties, the United States began pushing Turkey to crack down on or abolish opium production. The general Turkish public was opposed to such a ban. After the 1971 intervention of the military in politics with a "Generals' Memorandum," the newly appointed Prime Minister Nihat Erim decided to ban opium production as well as its sale and distribution. The ban went into full effect in the summer of 1973 and affected some 70,000 Turkish farmers. ${ }^{22}$ Soon after, Prime Minister Bulent Ecevit, whose People's Republican Party (CHP) won the elections in October 1973 and formed a coalition government with Necmettin Erbakan's National Salvation Party (MSP), duly reversed the ban. ${ }^{23}$

All through these years that passed with ups and downs in bilateral relations, Ankara and Washington were able to find breakthroughs, sooner or later, as decision-makers on both sides acknowledged that they would be better off if they moved forward. But recently, especially in the aftermath of the coup attempt on 

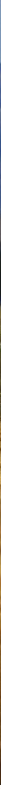

A Russian

AN-124 cargo

July 15, 2016 engineered by the Fetullahçı Terör Örgütü (FETÖ), Turkey and the United States have been experiencing major difficulties in their bilateral relations due mainly to two reasons. First, the Obama Administration's delayed and ultimately meager denunciation of the coup attempt, which far from satisfied the expectations of Turkish authorities from a close ally in terms of its timing and its semantics. Second, the spiritual leader of FETÖ, namely Fetullah Gülen, is allowed to reside in the United States despite the repeated official requests of Turkish authorities for his extradition to Turkey for a possible trial in the court of law. In addition to this unpleasant topic that has marred the spirit of the alliance in both capitals, Turkish-American relations have been considerably strained over the substantial and sustained logistical and other support of the United States to the YPG/PYD (Yekîneyên Parastina Gel, Partiya Yekitiya Demokrat) even though the group is listed by the State Department as a terrorist organization. The YPG/PYD, which claims to control the northeastern parts of Syria, is identified by Turkey as an extension of the PKK (Partiya Karkerên Kurdistanê) separatist terrorist organization, which is responsible for the killing of more than 50,000 Turkish citizens in their terror attacks. Notwithstanding the sensitivities of Turkey in its fight against this separatist terrorist nexus, the United States has given the YPG/PYD tens of thousands of trucks loaded with a variety of weapons, rockets and munitions as well as training and intelligence, none of which would be compatible with the actions of an ally.

Moreover, Turkey's profile has much worsened in the eyes of most politicians in Washington, particularly after Ankara's decision to buy the Russian air defense 
systems known as the S-400s. Democrats as well as Republicans in Congress have voted in a bipartisan manner to pass legislation that imposes tough sanctions on Turkey, including the armed forces and the military-industrial complex that have very close relations with their American counterparts. ${ }^{24}$ To add insult to injury, renowned scholars and think-tanks, as well as leading journalists and intellectuals across the United States have lined up to do their part by issuing very harsh statements about Turkey. This was, to say the least, an unacceptable and undeserved attitude displayed by a multitude of actors toward a decades-long ally like Turkey, which has always displayed its desire to buy advanced air defense capability from the United States, but to no avail. ${ }^{25}$ This and other similar negative stances toward Turkish demands was probably due to the efforts of an anti-Turkey coalition that funneled one-sided and distorted information into the decision-making circles on Capitol Hill. It is worth noting that the extent of the damage that might be caused by such an attitude in the relations between Ankara and Washington may have serious consequences for both sides beyond their anticipation. This assessment becomes even more true under the unprecedentedly dire conditions caused by the pandemic that are being experienced worldwide. All nations, regardless of their geographical size, military capabilities, industrial and technological infrastructure, or economic capacity have figured out that they may very well need each other in one way or another.

During the darkest days of the pandemic, when the spread of the virus gained a rather high pace particularly in Europe, Turkey emerged as a life-saver, acting much faster and more generously than the now 30-member NATO. Turkey reached out to its allies and partners, extending from Italy, Spain and the United Kingdom to Bulgaria, Hungary and Macedonia, providing them with a variety of medical aid and technical apparatuses such as ventilators, which were dearly and urgently needed for their infected citizens under treatment in intensive care units. NATO Secretary-General Jens Stoltenberg praised Turkey's efforts in his message on April 1, 2020, saying, "NATO solidarity in action: Turkey sending a cargo plane with medical supplies to Italy and Spain today to support our joint fight against COVID-19. Proud to see NATO Allies supporting each other through our disaster relief center." ${ }^{26}$

Turkey also provided the United States with some technical parts that are produced in Turkey, which are said to be highly crucial for the production of ventilators. At that time, because of the pandemic, however, these crucial parts were temporarily banned from being exported by the Turkish government as a precautionary measure. In addition to the large sums of medical aid, Turkey also delivered N95 masks, gowns and a variety of other kinds of protective gear for healthcare professionals in two separate missions on board the huge A400 M type military cargo airplane Koca Yusuf, named after the legendary Turkish world wrestling champion in the 1890s. U.S. Secretary of State Mike Pompeo acknowledged Turkey's aid sincerely by saying, "We are grateful for our NATO 
Ally Turkey. Their support is helping U.S. companies who are doing good work to help fight COVID19 around the world. We will get through this together, and come out stronger than before" in his message on May 3, 2020. ${ }^{27}$

This calls to mind a popular saying in Turkish culture, kötü gün dostu olmak (friends for bad times) that underscores and appreciates the value of displaying true friendship in difficult times, especially during periods of hardship, such as the one caused by

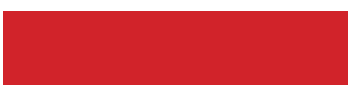

The European Union is said to be a net loser on all fronts and soon to be broke in the fight against the virus COVID-19 currently, when it is really needed, rather than showing off ostensibly friendly behavior during 'business as usual' periods. Turkey's prompt response to the urgent requests for medical aid coming from its allies in one of the darkest periods of the history of the Alliance perfectly fits this type of an approach in terms of friendship and solidarity, which stems from its longstanding imperial heritage and well-established modern statecraft.

It wouldn't be wrong to argue that such an approach has had a decisive impact on critical junctures in the modern-day history of relations between Turkey and the United States. The Marshall Aid, for instance, comes to mind as the generous American initiative in 1948 to heal the wounds of the Second World War across the war-torn European continent, which also sowed the seeds of the rapprochement between Turkey and the United States.

Similarly, Turkey's involvement in the Korean War with a brigade in 1950 was, in some sense, a reciprocation by Turkish authorities to display their resolve to build a new world order where aggression would not be tolerated and thus necessitated the response of collective action on the part of like-minded, peace-loving nations. Turkish casualties were, 721 martyrs killed in action (KIA), 175 missing in action (MIA), 234 prisoners of war (POW), and 2,147 wounded in action (WIA), out of the 5,090 soldiers and officers in the Turkish Brigade who were deployed on the Korean Peninsula. ${ }^{28}$ With these figures, Turkey ranked second after the United States with a very high casualty rate of 22 percent. This, by any measure, was a great sacrifice for the Turks, which was properly appreciated by the Americans, and which paved the way for forging a powerful and long-term alliance relationship within NATO starting from 1952.

Back in the 1950s, at the beginning of the nuclear age, when too many unknowns were tickling the minds of the drafters of foreign and security policies of governments around the world, wondering about what the world would look like in the face the challenges arising from ideological antagonism, Turkey and the United States decided to deepen their relations. No doubt, the key factor that influenced the attitude of the decision-makers in Washington in 
promoting Turkey's membership in NATO was its willingness as well as capability to share the burden with like-minded countries in an uncertain environment full of many security risks.

At present, the future looks no more certain than it did in the early years of the Cold War, nor is it more promising with respect to tackling the risks and challenges standing in the way as a result of the pandemic. Turkey has manifested in an undisputable manner that it is both capable and willing to share the burden of dealing with the menace that is being brought upon the world community by COVID-19.

Essentially, the European Union is said to be a net loser on all fronts and soon to be broke in the fight against the virus. Many Middle Eastern regimes are stumbling into deeper turmoil, both at home and among themselves. China, once seen as a benign alternative to U.S. superpower, is losing its edge and thin layer of soft power that used to be hailed thanks to its capital accumulation and much-propagated Belt and Road Initiative. But now, China is detested due to its perceived key role in the outbreak of the pandemic. At such a time, American politicians, scholars, think-tanks, journalists, and intellectuals who had lined up in harshly criticizing Turkey and suggesting that it be expelled from NATO and denied any military sales or economic benefits by the United States, should ask themselves what matters to them more than ever, and who do they see when they look from Washington, within the range of thousands of miles to the east, as a reliable and dependable partner that is willing and able to side with them while confronting the challenges in the post-COVID, so-called 'new normal' international order. Turkey stands out as the answer.

\section{Endnotes}

1. Lisa Schnirring, "WHO: Europe Now World's COVID-19 Epicenter," Center for Infectious Disease Research and Policy, (March 13, 2020), retrieved May 8, 2020, from https://www.cidrap.umn.edu/news-perspective/2020/03/who-europe-now-worlds-covid-19-epicenter.

2. Itty Abraham, "Four Future Scenarios, or, What's Different about the Covid-19 Crisis?," The India Forum, (May 1, 2020), retrieved May 10, 2020, from https://www.theindiaforum.in/article/what-s-differentabout-covid-19-crisis.

3. Zachary Abuza, "Weapons, Viruses, and the New Defense Reality in Southeast Asia," War on the Rocks, (May 7, 2020), retrieved May 9, 2020, from https://warontherocks.com/2020/05/weapons-viruses-andthe-new-defense-reality-in-southeast-asia/.

4. Ashley J. Tellis, "Covid-19 Knocks on American Hegemony," The New Normal in Asia, (May 4, 2020), retrieved May 9, 2020, from https://www.nbr.org/wp-content/uploads/pdfs/publications/new-normal-tellis-050420.pdf.

5. James Crabtree, "The End of Emerging Markets?," Foreign Policy, (May 3, 2020), retrieved May 9, 2020, from https://foreignpolicy.com/2020/05/03/emerging-markets-coronavirus-pandemic-economic-fallout/.

6. Nikolas K. Gvosdev, "Why the Coronavirus Won't Transform International Affairs Like 9/11 Did," The National Interest, (May 5, 2020), retrieved May 9, 2020, from https://nationalinterest.org/feature/why-coronavirus-wont-transform-international-affairs-911-did-151126. 
7. Remarks of Ambassador Burak Akçapar during a Zoom meeting on "Pandemi Sonrası Uluslararası Politika" (International Politics after the Pandemic) organized by the International Relations and DiplomacyClub (@irdcsabanci) at Sabancı University, İstanbul, May 10, 2020.

8. Edward Fishman, "The World Order Is Dead. Here's How to Build a New One for a Post-Coronavirus Era," Politico, (March 5, 2020), retrieved May 9, 2020, from https://www.politico.com/news/magazine/2020/05/03/the-post-coronavirus-world-order-230042.

9. Josep Borrell, "The Post-Coronavirus World Is Already Here," Policy Brief, European Council on Foreign Relations, (April 2020), retrieved May 9, 2020, from https://www.ecfr.eu/page/-/the_post_coronavirus_ world_is_already_here.pdf.

10. Mehdi Sanaei, "World Order in Post-Coronavirus Era," Expert Opinions, Valdai Club, (April 21, 2020), retrieved May 10, 2020, from https://valdaiclub.com/a/highlights/world-order-in-post-coronavirus-era/.

11. İbrahim Kalın, "Ciphers of Post-Coronavirus World: National Self-Sufficiency and Global Cooperation," Anadolu Agency, (April 22, 2020), retrieved May 10, 2020, from https://www.aa.com.tr/en/analysis/ ciphers-of-post-coronavirus-world-national-self-sufficiency-and-global-cooperation/1815272\#.

12. As of June 18,2020 , the total number of cases in the world had reached 8,242,999, with 445,535 deaths, and counting. "WHO Coronavirus Disease (COVID-19) Dashboard," WHO, retrieved June 18, 2020, from https://covid19.who.int/.

13. Akçapar, "Pandemi Sonrası Uluslararası Politika."

14. Kevin Rudd, "The Coming Post-COVID Anarchy," Foreign Affairs, (May 6, 2020), retrieved May 9, 2020, from https://www.foreignaffairs.com/articles/united-states/2020-05-06/coming-post-covid-anarchy.

15. Ka-Ho Wong, "Should China Worry About the Russia-US Reset?," The Diplomat, (May 8, 2020), retrieved May 10, 2020, from https://thediplomat.com/2020/05/should-china-worry-about-the-russia-us-reset/.

16. James Carafano, "How to Keep the Free World from Becoming a Suburb of Beijing," The Daily Signal, (May 4, 2020), retrieved May 9, 2020, from https://www.dailysignal.com/2020/05/04/how-to-keep-thefree-world-from-becoming-a-suburb-of-beijing/.

17. Arvind Subramanian, "The Threat of Enfeebled Great Powers," Project Syndicate, (May 6, 2020), retrieved May 9, 2020, from https://www.project-syndicate.org/commentary/covid19-will-weaken-united-states-china-and-europe-by-arvind-subramanian-2020-05.

18. Jan Techau, "Saving Europe from Corona's Nasty Geopolitics," EUobserver, (April 15, 2020), retrieved May 10, 2020, from https://euobserver.com/opinion/148057.

19. Khairallah Khairallah, "The Upcoming Middle East Upheaval in the Post-COVID-19, post-Oil Crisis World," The Arab Weekly, (April 26, 2020), retrieved May 11, 2020, from https://thearabweekly.com/upcoming-middle-east-upheaval-post-covid-19-post-oil-crisis-world.

20. Mustafa Kibaroğlu, "La Turquie, Les États-Unis et L'OTAN: Une Alliance Dans L'Alliance," Questions Internationales, No. 12 (March-April 2005), pp. 30-32.

21. James W. Spain, "The United States, Turkey and the Poppy," Middle East Journal, Vol. 29, No. 3 (Summer, 1975), pp. 295-309.

22. Juan de Onis, "Opium Poppy Gone, Turkish Farmers Ask Why Has U.S. Done This to Us?," The New York Times, (August 9, 1973).

23. "A Brief History of U.S.-Turkey Tensions (1960-2017)," Turkish Heritage Organization, (November 22, 2017), retrieved May 5, 2020, from https://www.turkheritage.org/Uploads/a-brief-history-of-u.s.-turkeytensions.pdf.

24. Mustafa Kibaroğlu, "On Turkey's Missile Defense Strategy: The Four Faces of the S-400 Deal Between Turkey and Russia," SAM Paper Series, No. 16 (April 2019), pp. 8-9.

25. Mustafa Kibaroğlu, "Turkey's Place in the Missile Shield Project," Journal of Balkan and Near Eastern Studies, Vol. 15, No. 2 (Summer, 2013), pp. 223-236.

26. Jens Stoltenberg, Twitter, 10:08 AM, (April 1, 2020), retrieved from https://twitter.com/jensstoltenberg/status/1245246529633497088.

27. Mike Pompeo, Twitter, 6:28 AM, (May 3, 2020), retrieved from https://twitter.com/SecPompeo/status/1256787761824239617.

28. Ünsal Sığrı and Ufuk Başar, "An Analysis of Turkish National and Military Culture in the Context of Korean War," Journal of World of Turks, Vol. 6, No. 3 (2014), p. 7. 


\section{THE PAGES \\ BRINGING YOU \\ THE WORLD}

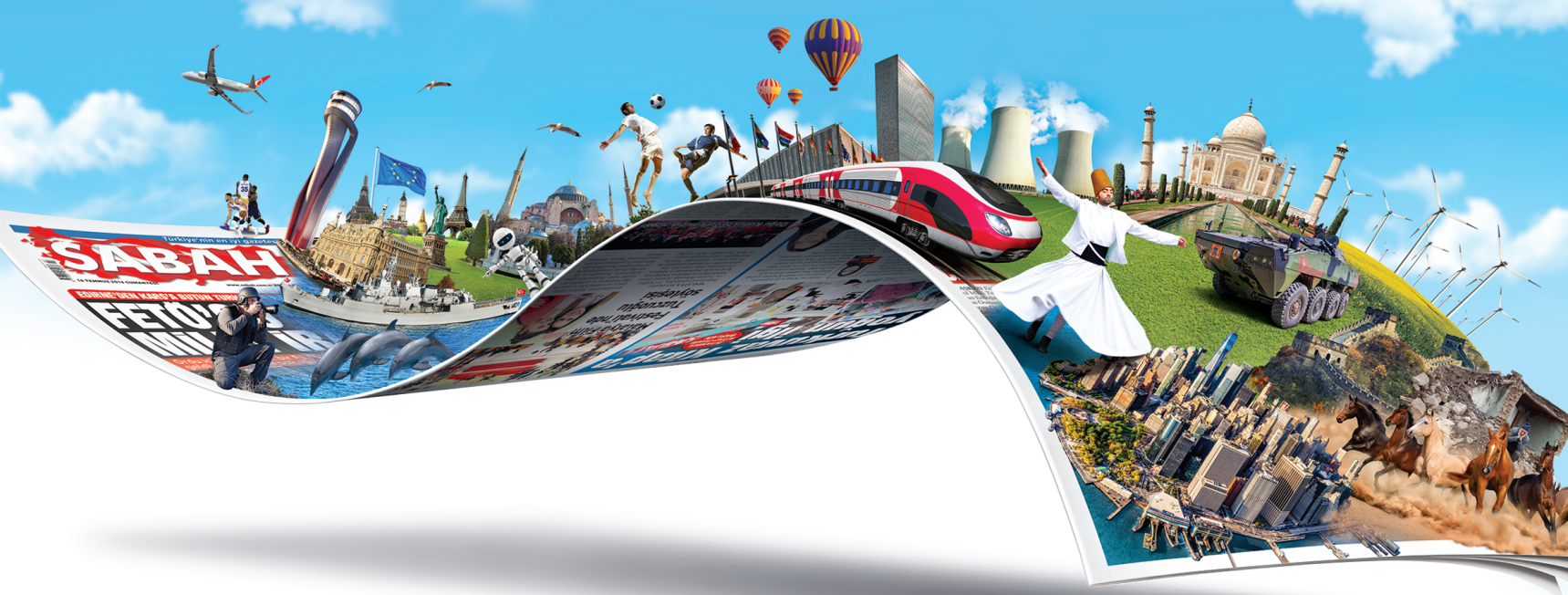

We write the truth, solely the truth.

without mincing any words.

Whatever is happening.

we bring it to you as it happens.

To us, the world is small,

but the power we derive from you is huge.

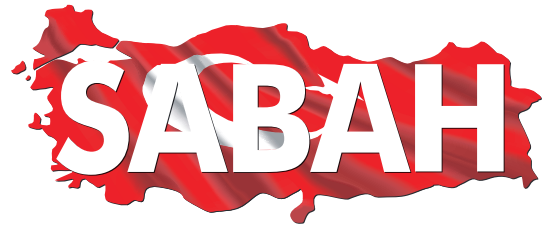

"Turkey's Newspaper" 